\title{
THE IMPACT OF COVID-19 PANDEMIC ON SYMPTOMATIC GALLSTONE DISEASE
}

\author{
Semptomatik Safra Kesesi Taşı Hastalı̆̆ında COVİD-19 Pandemisinin Etkisi
}

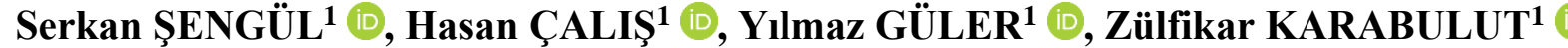

${ }^{1}$ Alanya Alaaddin Keykubat University, Faculty of Medicine, Dept. of General Surgery Alanya, ANTALYA, TÜRKIYYE

Objective: After the COVID-19 pandemic was declared, many centers made alterations in their routine surgical treatments. In this study, we aimed to compare patients who underwent cholecystectomy for symptomatic gallstone disease during the pandemic and pre-pandemic periods.

Material and Methods: Two groups were formed in this study; the pandemic group consisting of patients with symptomatic gallstone disease who underwent surgery between March 112020 and January 31 2020, and the prepandemic group consisting of patients who were operated in the same period of 2019. These two groups were compared in terms of demographic data, conversion rates and histopathology results.

Results: A total of 293 patients were included in the study. Two hundred and seven patients took part in the pre-pandemic period and 86 in the pandemic period. The rate of conversion to open cholecystectomy was $2.8 \%(\mathrm{n}=6)$ in the pre-pandemic group and $6.9 \%(n=6)$ in the pandemic group. However, there was no statistically significant difference between the groups in terms of conversion rates $(\mathrm{p}=0.10)$. The gallbladder wall thickness was significantly higher in the pandemic group compared to the pre-pandemic group $(3.2 \pm 1.7 \mathrm{~mm}$ vs. $2.7 \pm 1.4$ $\mathrm{mm}, \mathrm{p}=0.009$ ). In the pandemic group, postoperative pathology was reported as subacute cholecystitis in $19.8 \%$ $(\mathrm{n}=17)$ of patients. In the pre-pandemic group, this rate was $11.1 \%(\mathrm{n}=23)(\mathrm{p}=0.04)$

Conclusion: Possible delays in the treatment of patients with symptomatic gallbladder stones during the pandemic period may lead to an increase in factors that may result in conversion to open surgery. However, further studies with large sample size are needed to elucidate this issue.

Keywords: COVID-19, pandemic, gallbladder stone, conversion
Amaç: COVID-19 pandemisi ilan edildikten sonra birçok merkez rutin uygulanan cerrahi tedavilerde değişikliklere gitti. Bu çalışmada semptomatik safra kesesi taşı hastalığı nedeni ile kolesistektomi uygulanan hastaları pandemi ve prepandemi döneminde karşılaştırmayı amaçladık.

Gereç ve Yöntemler: Çalışma için semptomatik safra kesesi taşı hastalığ olan, 11.03.2020-31.12.2020 tarihleri arasında opere edilen hastalardan oluşan pandemi grubu ve 2019 yılının aynı döneminde ameliyat edilen hastalardan oluşan prepandemi grubu olmak üzere iki grup oluşturuldu. Bu iki grup demografik veriler, konversiyon oranları ve patoloji sonuçları açısından karşılaştırıldı.

Bulgular: Toplamda 293 hasta çalışmaya dahil edildi. $\mathrm{Bu}$ hastaların 207'si prepandemi döneminde 86' s1 ise pandemi döneminde yer aldı. Prepandemi grubunda açık kolesistektomiye dönen hasta $\% 3(n=6)$, pandemi grubunda ise $\% 7(n=6)$ olarak bulundu. Ancak konversiyon oranları açısından gruplar arasında anlamlı fark yoktu $(\mathrm{p}=0,10)$. Pandemi grubunda kese duvar kalınlığı prepandemi grubuna

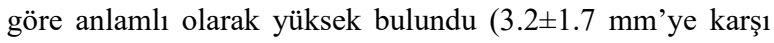
$2.7 \pm 1,4 \mathrm{~mm}, \mathrm{p}=0,009)$. Pandemi grubunda postoperatif patoloji sonucu \%20 $(\mathrm{n}=17)$ hastada subakut kolesistit olarak raporland1. Prepandemi grubunda ise bu oran \%11 $(n=23)$ olarak bulundu $(\mathrm{p}=0,04)$.

Sonuç: Pandemi döneminde semptomatik safra kesesi taş1 nedeni olan hastaların tedavilerindeki olası gecikmeler konversiyona neden olabilecek faktörlerde artışa neden olabilir. Ancak bu konuda yüksek sayıda örneklem içeren çalışmalara ihtiyaç duyulmaktadır.

Anahtar Kelimeler: COVID-19, pandemi, safra kesesi taşı, konversiyon 


\section{INTRODUCTION}

In early December 2019, several hospitals in Wuhan city in Hubei province of China reported an increasing number of pneumonia patients due to infection with an unknown virus. Studies revealed that the virus causing pneumonia was severe acute respiratory syndrome coronavirus 2 (SARS-CoV) (1). SARS-CoV-2, previously known as 2019-nCoV, is a newly emerged RNA virus belonging to the Coronaviridae family (2). The disease caused by the virus was named Coronavirus Disease 2019 (COVID-19) and a pandemic was declared by the World Health Organization on March 11, 2020 (3).

After the declaration of COVID-19 pandemic, major surgical societies published their official recommendations describing their approach to general surgery diseases. In this context, delaying some nonurgent surgeries to use hospital resources and intensive care capacities appropriately during the pandemic has also been an approach applied in our country.

The incidence of gallbladder stones has been reported as approximately $20 \%$ in Europe, and it is the most common disease that leads to hospitalization in gastroenterology clinics (4). The clinical course of gallstone disease can range from asymptomatic state to symptomatic disease without complications with biliary colic, and complex symptomatic diseases such as acute cholecystitis, common bile duct stones, pancreatitis, cholangitis and rarely, intestinal obstruction (5). Cholecystectomy is the preferred treatment modality for symptomatic gallstones. (6).

The aim of this study was to compare the conversion rates and pathology results of patients who underwent laparoscopic cholecystectomy due to symptomatic gallbladder disease in the period after the pandemic was declared (March 11, 2020) and during the same period of the previous year.

\section{MATERIALS AND METHODS}

This study was conducted retrospectively after the approval of Alanya Alaaddin Keykubat University Medical Faculty Ethics Committee of Clinical Research (Date: 27.01.2021; issue number: 02-13). Patients over 18 years of age who were diagnosed with symptomatic gallstones (abdominal pain, dyspepsia, indigestion, bloating, etc.) in the general surgery outpatient clinic during the specified date intervals between 2019 and 2020 and who underwent laparoscopic cholecystectomy under elective conditions were included in the study. Patients who were taken into emergency surgery due to acute cholecystitis, acute biliary pancreatitis, and patients with a history of previous abdominal surgery, diabetes mellitus, obesity were excluded from the study. The patients were divided into 2 groups. Patients who underwent surgery between March 11, 2020 (the date pandemic was declared) and December 31, 2020, were classified as pandemic group. Patients who underwent surgery between the same dates of the previous year (11.03.2019 and 31.12.2019) were classified as the prepandemic group. Age, gender, pathology results, gallbladder wall thickness and conversion rates were compared between the groups.

Polymerase chain reaction test was performed for COVID-19 disease 24 hours before the elective operation in all patients in the pandemic group. Positive patients were not included in the study.

\section{Statistical Analyses}

The statistical analysis was performed using SPSS (version 20.0 for Mac; SPSS, Inc, an IBM Company, Chicago, IL) software. The distribution between the groups was assessed by the Kolmogorov-Smirnov test. When the findings were not normally distributed, the nonparametric Mann-Whitney $U$ test was used to compare the data. A p value $<0.05$ was considered statistically significant. 


\section{RESULTS}

Cholecystectomy was performed for symptomatic gallstones in 207 patients during the pre-pandemic period and in 86 patients during the pandemic period. The mean age of these patients was $50.9 \pm 13.3$ years in the pre-pandemic group and $49.4 \pm 14$.6 years in the pandemic group $(\mathrm{p}=0.41)$. One hundred thirty-eight $(67.1 \%)$ of the patients in the pre-pandemic group and $59(68.6 \%)$ of the patients in the pandemic group were women. Gender distribution was similar between the two groups $(\mathrm{p}=0.46)$.

Postoperative pathology examinations of the patients who underwent surgery in the pre-pandemic period were reported to be compatible with subacute cholecystitis in $11.1 \%(n=23)$ and $19.8 \%(n=17)$ in the pre-pandemic and pandemic groups, respectively $(\mathrm{p}<0.05)$. Conversion rates were $2.8 \%(n=6)$ in the pre-pandemic group and $6.9 \%(n=6)$ in the pandemic group $(p=0.1)$. The demographic data of the patients and the distribution between the groups are shown in Table 1 . The gallbladder wall thickness was significantly higher in the pandemic group compared to the pre-pandemic group (3.2 $\pm 1.7 \mathrm{~mm}$ vs. $2.7 \pm 1.4 \mathrm{~mm}, \mathrm{p}=0.009)$.

When the reasons for the conversion to open cholecystectomy were considered, increased gallbladder wall thickness was encountered in $50 \%(n=3)$, bleeding from the gallbladder bed occurred in $16.6 \%(n=1)$ and adhesions were found around the gallbladder in $33.3 \%$ $(n=2)$ of patients in the pandemic group. The reasons for conversion to open cholecystectomy during pandemic and pre-pandemic periods are shown in Table 2.

Table 1: Comparison of patients in both groups

\begin{tabular}{lccc}
\hline & $\begin{array}{c}\text { Pre-pandemic } \\
\mathrm{n}=207\end{array}$ & $\begin{array}{c}\text { Pandemic } \\
\mathrm{n}=86\end{array}$ & P-value \\
\hline Age $($ mean $\pm \mathrm{SD})$, years & $50.9 \pm 13.3$ & $49.4 \pm 14.6$ & 0.41 \\
\hline Gender & $139(67.1)$ & $59(68.6)$ & 0.46 \\
Female, $\mathrm{n}(\%)$ & $68(32.9)$ & $27(31.4)$ & 0.04 \\
Male, $\mathrm{n}(\%)$ & & $17(19.8)$ & \\
\hline Pathology, $\mathrm{n}(\%)$ & $23(11.1)$ & $69(80.2)$ & $3.2 \pm 1.7$ \\
$\quad$ Subacute cholecystitis & $184(88.9)$ & $6(6.9)$ & 0.009 \\
Chronic cholecystitis & $2.7 \pm 1.4$ & 0.10 \\
\hline Gallbladder wall thickness (millimeter) & $6(2.8)$ & & \\
\hline Conversion, $\mathrm{n}(\%)$ & & & \\
\hline
\end{tabular}

SD: Standard deviation

Table 2: Reasons for conversion to open cholecystectomy

\begin{tabular}{lcc}
\hline & Pre-pandemic & Pandemic \\
& $\mathrm{n}(\%)$ & $\mathrm{n}(\%)$ \\
Hemorrhage from cystic artery & $1(16.6)$ & - \\
\cline { 2 - 3 } Hemorrhage from gallbladder bed & $1(16.6)$ & $1(16.6)$ \\
Adhesion around the gallbladder & $3(50.0)$ & $2(33.3)$ \\
Thickened gallbladder wall & $1(16.6)$ & $3(50.0)$ \\
\hline
\end{tabular}




\section{DISCUSSION}

COVID-19 virus has emerged as an epidemic that threatened human life all over the world and had a negative impact on the quality of life. In order to get a control over this deadly virus, comprehensive measures are in place for prevention of person-to-person transmission. Among these measures, "stay at home" warning is accepted as the most effective method. After the COVID-19 pandemic was declared, changes in treatment strategies were implemented in many countries and hospitals regarding non-emergency surgical interventions. However, numerous major surgical societies have recommended postponement of elective surgery when possible $(7,8)$. In this study, the aim was to investigate the impact of possible delays in the treatment of patients with symptomatic gallstones due to "stay at home" calls made to the public and surgeons' approach to elective surgery.

All current guidelines recommend laparoscopic cholecystectomy as the gold standard treatment method since it yields better results in terms of mortality, morbidity and postoperative hospital stay compared to open cholecystectomy in gallstone disease $(9,10)$. However, SARS-CoV-2 RNA has been also recently detected in the peritoneal cavity (11). Therefore, it is assumed that the carbon dioxide administered into the abdomen in laparoscopic technique may increase the risk of COVID-19 transmission for the surgical team by creating an aerosol (12). However, no evidence was found to suggest that the risk of laparoscopic cholecystectomy-related COVID-19 infection could be higher than open cholecystectomy, neither for the patient nor for healthcare professionals. Therefore, no changes have been made in terms of operation technique in our clinic.

The conversion rates from laparoscopic cholecystectomy to open cholecystectomy have been reported between $2.6 \%$ and $7.7 \%$ in various studies $(13,14)$. Conversion rates and complications observed during cholecystectomy vary depending on factors such as surgeon's experience, previous abdominal surgery, presence of cholecystitis attacks, acute cholecystitis, male gender, and advanced age (15). However, conversion should not be seen as a complication and should be considered as an important method in preventing complications when necessary. In this study, emergency operations due to acute cholecystitis were not included, hence the conversion rate was $2.8 \%$ during the pre-pandemic period and $6.9 \%$ during the pandemic period, and these rates seem to be consistent with those reported in literature. Furthermore, gallbladder wall thickness has been considered as a risk factor in terms of conversion in some studies $(16,17)$. In the present study, the gallbladder wall thickness was significantly higher during the pandemic period compared to the prepandemic period. Again, in this study, regarding postoperative pathology findings, the number of patients reported as subacute cholecystitis was significantly higher in patients who underwent surgery during the pandemic period.

These results suggest that some delays can occur in the treatment of patients who underwent surgery for symptomatic gallstones during the pandemic period. From the perspective of patients, many people assume hospitals to be the most "dangerous places" where they are much more likely to be infected by the new coronavirus. From the surgeon's point of view however, several factors may play a role in this delay. One of these is the detection of the serious effects of COVID-19 disease that can be observed in the postoperative period during the incubation period. In their retrospective study, Lei et al. evaluated 34 patients (with COVID-19 disease during the incubation period) who underwent elective surgery (18). Approximately $44 \%$ of patients had to be hospitalized in intensive care due to respiratory failure and they reported a total mortality rate of $20 \%$. Similarly, in the case series reported from Iran, it was reported that postoperative pulmonary complications developed after uneventful elective operations 
(incisional hernia repair, cholecystectomy, cholecystectomy) in 3 patients during the incubation period of COVID-19 (19). These findings led surgeons to consider the "first do no harm" principle of medical ethics while performing elective surgeries.

There were some limitations in our study. First, it was a retrospective study and had a relatively low sample size. Secondly, new information and evidence is emerging day by day regarding the COVID-19 disease, its pathogenesis, and its impact on the health system. In conclusion, the evidence base surrounding the results obtained in this study may change in the future.

COVID-19 has caused a pandemic that had a serious impact on the entire healthcare system worldwide. In this period, delays due to the patient or surgeon may be encountered in the treatment of patients admitted with symptomatic gallstones. This delay may adversely affect factors that may lead to conversion to open surgery (such as gallbladder wall thickness and subacute cholecystitis) in patients undergoing laparoscopic cholecystectomy. In fact, serious morbidity and mortality may increase because of this disease, which is seen as a benign pathology. Further multi-center studies with higher sample size would be able to yield more precise results.

Conflict of Interest: The authors declare that they have no conflict of interest.

Support and Acknowledgment: There is no funding source.

Researchers' Contribution Rate Statement: The authors declare that they have contributed equally to the article. Concept-Design: SS, HC, ZK; Analysis-Interpretation: HC, YG; Data Collection: SS, YG; Writing Manuscript: HC, SS; Critical Review: YG, ZK. All authors have read and approved the final form of the manuscript.

Ethics Committe Aproval: Alanya Alaaddin Keykubat University Medical Faculty Ethics Committee of Clinical Research, date: 27.01.2021; issue number: 0213.

\section{REFERENCES}

1. Li Q, Guan X, Wu P, Wang X, Zhou L, Tong Y et al. Early transmission dynamics in Wuhan, China, of novel coronavirus-infected pneumonia. N Engl J Med. 2020;382(13):1199-207.

2. Benvenuto D, Giovanetti M, Ciccozzi A, Spoto S, Angeletti S, Ciccozzi M. The 2019-new coronavirus epidemic: evidence for virus evolution. J Med Virol. 2020;92(4):455-9.

3. Parreira JG, Campos TD, Antunes PDSL, Perlingeiro JAG, Assef JC. Management of nontraumatic surgical emergencies during the COVID19 pandemia. Rev Col Bras Cir. 2020;47:e20202614.

4. Lammert F, Acalovschi M, Ercolani G, van Erpecum KJ, Gurusamy K, van Laarhoven CJ et al. EASL Clinical Practice Guidelines on the prevention, diagnosis and treatment of gallstones. J Hepatol. 2016;65(1):146-81.

5. Shabanzadeh DM. Incidence of gallstone disease and complications. Curr Opin Gastroenterol. 2018;34(2):81-9.

6. Brazzelli M, Cruickshank M, Kilonzo M, Ahmed I, Stewart F, McNamee P et al. Systematic review of the clinical and cost effectiveness of cholecystectomy versus observation/conservative management for uncomplicated symptomatic gallstones or cholecystitis. Surg Endosc. 2015;29(3):637-47.

7. Campanile FC, Podda M, Arezzo A, Botteri E, Sartori A, Guerrieri M et al. Acute cholecystitis during COVID-19 pandemic: a multisocietary position statement. World J Emerg Surg. 2020;15(1):38.

8. Moletta L, Pierobon ES, Capovilla G, Costantini M, Salvador $\mathrm{R}$, Merigliano $\mathrm{S}$ et al. International guidelines and recommendations for surgery during Covid-19 pandemic: a systematic review. Int J Surg. 2020;79:180-8. 
9. Ansaloni L, Pisano M, Coccolini F, Peitzmann A, Fingerhut A, Catena F et al. 2016 WSES guidelines on acute calculous cholecystitis. World J Emerg Surg. 2016;11:25.

10. Agresta F, Campanile FC, Vettoretto N, Silecchia G, Bergamini C, Maida $\mathrm{P}$ et al. Laparoscopic cholecystectomy: consensus conference-based guidelines. Langenbecks Arch Surg. 2015;400(4):429-53.

11. Coccolini F, Tartaglia D, Puglisi A, Giordano C, Pistello M, Lodato M et al. SARS-CoV-2 is present in peritoneal fluid in COVID-19 patients. Ann Surg. 2020;272(3):e240-e242.

12. Kamer E, Çolak T. What to do when a patient infected with COVID-19 needs an operation: a presurgery, peri-surgery and post-surgery guide. Turk J Colorectal Dis. 2020;30(1):1-8.

13. Avgerinos C, Kelgiorgi D, Touloumis Z, Baltatzi L, Dervenis C. One thousand laparoscopic cholecystectomies in a single surgical unit using the "critical view of safety" technique. J Gastrointest Surg. 2009;13(3):498-503.

14. Pavlidis TE, Marakis GN, Ballas K, Symeonidis N, Psarras K, Rafailidis S et al. Risk factors influencing conversion of laparoscopic to open cholecystectomy. J Laparoendosc Adv Surg Tech A. 2007;17(4):4148 .

15. Genc V, Sulaimanov M, Cipe G, Basceken SI, Erverdi N, Gurel $\mathrm{M}$ et al. What necessitates the conversion to open cholecystectomy? A retrospective analysis of 5164 consecutive laparoscopic operations. Clinics (Sao Paulo). 2011;66(3):417-20.

16. Rothman JP, Burcharth J, Pommergaard H-C, Viereck S, Rosenberg J. Preoperative risk factors for conversion of laparoscopic cholecystectomy to open surgery-a systematic review and meta-analysis of observational studies. Dig Surg. 2016;33(5):414-23.
17. Low S-W, Iyer SG, Chang SK-Y, Mak KS, Lee VTW, Madhavan K. Laparoscopic cholecystectomy for acute cholecystitis: safe implementation of successful strategies to reduce conversion rates. Surg Endosc. 2009;23(11):2424-9.

18. Lei S, Jiang F, Su W, Chen C, Chen J, Mei W et al. Clinical characteristics and outcomes of patients undergoing surgeries during the incubation period of COVID-19 infection. E Clinical Medicine. 2020;21:100331.

19. Aminian A, Safari S, Razeghian-Jahromi A, Ghorbani M, Delaney CP. COVID-19 outbreak and surgical practice: unexpected fatality in perioperative period. Ann Surg. 2020;272(1):e27e29. 